\title{
Waste-Based Second-Generation Bioethanol: A Solution for Future Energy Crisis
}

\author{
Yasindra S. Chandrasiri1, W.M. Lakshika I. Weerasingheㄹ, D.A. Tharindu Madusanka ${ }^{1}$, \\ Pathmalal M. Manage $12^{*}$
}

\begin{abstract}
${ }^{1}$ Centre for Water Quality and Algae Research, Department of Zoology, University of Sri Jayewardenepura, Gangodawila, Nugegoda, 10250, Sri Lanka
\end{abstract}

${ }^{2}$ Faculty of Graduate Studies, University of Sri Jayewardenepura, Gangodawila, Nugegoda, 10250, Sri Lanka

\begin{abstract}
The demand for more environmentally friendly alternative renewable fuels is growing as fossil fuel resources are depleting significantly. Consequently, bioethanol has attracted interest as a potentially viable fuel. The key steps in second-generation bioethanol production include pretreatment, saccharification, and fermentation. The present study employed simultaneous saccharification and fermentation (SSF) of cellulose through bacterial pathways to generate second-generation bioethanol utilizing corncobs and paper waste as lignocellulosic biomass. Mechanical and chemical pretreatments were applied to both biomasses. Then, two bacterial strains, Bacillus sp. and Norcadiopsis sp., hydrolysed the pretreated biomass and fermented it along with Achromobacter sp., which was isolated and characterized from a previous study. Bioethanol production followed by $72 \mathrm{~h}$ of biomass hydrolysis employing Bacillus sp. and Norcadiopsis sp., and then $72 \mathrm{~h}$ of fermentation using Achromobacter sp. Using solid phase micro extraction combined with GCMS the ethanol content was quantified. SSF of alkaline pretreated paper waste hydrolysed by Bacillus sp. following the fermentation by Achromobacter sp. showed the maximum ethanol percentage of $0.734 \pm 0.154$. Alkaline pretreated corncobs hydrolyzed by Norcadiopsis sp. yielded the lowest ethanol percentage of $0.155 \pm 0.154$. The results of the study revealed that paper waste is the preferred feedstock for generating second-generation bioethanol. To study the possible use of ethanol-diesel blends as an alternative biofuel E2, E5, E7, and E10 blend emulsions were prepared mixing commercially available diesel with ethanol. The evaluated physico-chemical characteristics of the ethanol-diesel emulsions fulfilled the Ceypetco requirements except for the flashpoint revealing that the lower ethanol-diesel blends are a promising alternative to transport fuels. As a result, the current study suggests that second generation bioethanol could be used as a renewable energy source to help alleviate the energy crisis..
\end{abstract}

Keywords: bacterial pathways, corncobs, ethanol-diesel blends, paper waste, SSF.

Article History: Received: $1^{\text {st }}$ Oct 2021 2021; Revised: 10 ${ }^{\text {th }}$ Nov 2021; Accepted: $18^{\text {th }}$ Nov 2021; Available online: $1^{\text {st }}$ Dec 2021

How to Cite This Article: Chandrasiri, Y.S., Weerasinghe, W.M.L.I., Madusanka, D.A.T., Pathmalal, M.M.. (2022) Waste-Based SecondGeneration Bioethanol: A Solution for Future Energy Crisis. International Journal of Renewable Energy Development, 11(1), 275-285 https://doi.org/10.14710/ijred.2022.41774

\section{Introduction}

With the increasing human population, urbanization, and industrial modernization, the global primary energy consumption is raising remarkably day by day (Zentou et al., 2019). According to the BP Stat Review report (2020), world energy consumption had risen by $1.3 \%$ in 2019 . All energy extracted from every single energy resource and consumed by humans almost in every sector in every country, including households, transportation, and industrial, would be included in global energy consumption (Lizunkov, 2018).

Given the present demand, it has anticipated that the current fossil fuel reserves will be exhausted within the next 40-50 years (Rastogi, and Shrivastava, 2017). Coal combustion also provides a significant contribution to the growing greenhouse gas emissions that contribute to global warming. Coal combustion is accountable for more than $70 \%$ emission of carbon monoxide (CO), $40 \%$ emission of nitrogen oxide (NOx), and 19\% emission of overall carbon dioxide $\left(\mathrm{CO}_{2}\right)$ (Halder et al., 2019). The fossil fuel reserve depletion, economic concerns, and rising global warming generated due to fossil fuel burning has sparked interest in new alternative energy sources. Biofuels are a type of bioenergy generated from abundant natural renewable energy sources, making them an attractive alternative to fossil fuel energy (Zentou et al., 2019). Biofuels made of solid biomass using some chemical and biological approaches. Bioethanol, biodiesel, bio char, bio hydrogen, syngas, and biogas are among the most popular biofuels on the market (Madusanka and Manage, 2018). Biofuels have increased in popularity and now are primarily used to replace conventional transport fuels (Kumari and Singh, 2018).

Bioethanol is a popular biomass-based biofuel among biofuels. Bioethanol is primarily used as a fuel extender,

\footnotetext{
*Corresponding author: pathmalal@sjp.ac.lk
} 
gasoline or diesel improver, or octane enhancer in bioethanol-diesel blends to reduce exhaust emissions (Odziemkowska, Matuszewska and Czarnocka, 2016). The four categories of bioethanol depending on the source are first-generation bioethanol, second-generation bioethanol, third-generation bioethanol, and fourth-generation bioethanol. (Sharma, Larroche and Dussap, 2020). Food crops with sugar and starch like molasses, cassava, and sweet sorghum (Farida, Syamsu and Rahayuningsih, 2015) are the source of first-generation bioethanol while second-generation bioethanol generated from non-edible lignocellulosic biomass. Third-generation and fourthgeneration bioethanol produced from algae and genetically modified microalgae, respectively (Mat et al., 2020).

Non-edible waste products including aquatic plants like water hyacinth, perennial grass like energy crops, forest materials like softwood, hardwood, sawdust, residues of pruning and thinning of bark, cereal straws, bagasse and stoves like residues generated in agriculture and also the Organic Fraction of Municipal Solid Waste (MSW) has received much attentiveness as feedstock for second-generation bioethanol production (Prasad et al., 2019; Weerasinghe, Madusanka and Manage, 2021). Primarily the lignocellulosic biomass is composed with cellulose (40-60\%), hemicellulose (20-35\%), and lignin (15$40 \%$ ), including minor amounts of ashes (Zoghlami and Pas, 2019). Material collection and preparation or pretreatment, hydrolysis, fermentation, product recovery and purification are the key steps involved in the process of bioethanol production using lignocellulosic biomass (Zabed et al., 2017). Chemical pretreatment, physical pretreatment, biological pretreatment, and physicchemical pretreatment are by far the most frequently employed pretreatment methods nowadays (Sun et al., 2016; Raud et al., 2019). The high surface area and the porosity of the biomass structure are enhanced during the pretreatment procedure (Figure 1) to improve sugar yields during hydrolysis (Wang, 2021).

Pretreatment technology, process conditions, and severity play a significant role in eliminating lignin and hemicellulose from lignocellulosic biomass and improving sugar yields (Loow et al., 2016). Hydrolysis can be accomplished in two ways: biologically (enzymatic hydrolysis) or chemically (acidic hydrolysis) (Aditiya et al., 2016). Microorganisms play a significant part in hydrolysing the lignocellulosic biomass enzymatically, which results in the production of enzymes that use in the saccharification process (Winarsih and Siskawardani, 2020). The sugars which are fermentable produced from hydrolysing lignocellulosic biomass are then utilized as the substrates for fermentation, which is a biological process in which a range of microbes produce energy from sugars (Branco, Serafim and Xavier, 2019).

To combine hydrolysis and fermentation bioprocesses different designs are applied. The most prevalent setups are Simultaneous Saccharification and Fermentation (SSF), Consolidated Bioprocessing (CPB) and Separate Hydrolysis and Fermentation (SHF) (Su et al., 2020; Weerasinghe, Madusanka and Manage, 2021). In SHF, both hydrolysis and fermentation steps are performed as two steps, one after the other. In a single reactor, SSF combines biomass hydrolysis with simultaneous fermentation of released sugars (Gupta et al., 2019). All of the required reactions in biomass bioconversion into ethanol are integrated with CPB that include enzyme production, enzymatic hydrolysis, and fermentation (Rastogi and Shrivastava, 2017). The resulted bioethanol in the fermented broth are recovered utilizing conventional or modified conventional systems which use distillation systems and utilizing nonconventional systems which use non-distillation systems. (Zentou et al., 2019). However, ethanol separation consumes energy intensively and therefore use of most energy efficient process is crucial (Sitompul, Widayat and Soerawidjaja, 2012).

Corncob is abundant and readily accessible throughout the world. The United States Department of Agriculture (USDA) estimates that, in 2018-2019 the global corn production would be 1098.95 million tons (https://www.usda.gov/). As a result, a considerable proportion of corncob residues generated yearly and afterwards thrown as solid waste, leading to a massive waste of resources and severe environmental issues (Yang et al., 2021). When considering paper waste as a lignocellulosic biomass for bioethanol production it is a promising feedstock because of it is highly abundant, costeffective, and have relatively high amount of carbohydrates. It can easily digest without aggressive physical or chemical pretreatments, and, most notably, waste paper for bioethanol production is very efficient (Nair, Lennartsson and Taherzadeh, 2017; Ojewumi et al., 2018). Bioethanol does have the potential to become a future energy crisis solution because it can be used directly in specially constructed engines or as lower blends in compression ignition (CI) engines without requiring any modifications. Bioethanol is used mainly in combinations with gasoline and diesel, making it an excellent fuel extender. This helps prolong the length of the remaining fossil fuel resources (Hagos et al., 2017; Branco, Serafim and Xavier, 2019; Weerasinghe, Madusanka and Manage, 2021). Also by adding ethanol into diesel reduce Greenhouse gas emission, which contributes to global warming (Al-Esawi, Qubeissi and Kolodnytska, 2019; Gao et al., 2019).

As a result, Sri Lanka, which is heavily reliant on fossil fuels, will undoubtedly face an energy crisis in the near future. Furthermore, there have been very few studies conducted in Sri Lanka on the production of bioethanol using waste products via biological pathways, and more research is required (Jayathilaka et al. 2018; Jayasekara, Abayasekara and Ratnayake, 2019; Senarathna, Rupasinghe and Bandara, 2019; Kularathne et al. 2020; Weerasinghe, Madusanka and Manage, 2021). Consequently, this particular study was undertaken to speculate the possibility of producing bioethanol using corncobs and paper waste as lignocellulosic biomass and Carboxy methylcellulose (CMC), as utilizing ethanol blended with diesel to meet the future energy crisis. 


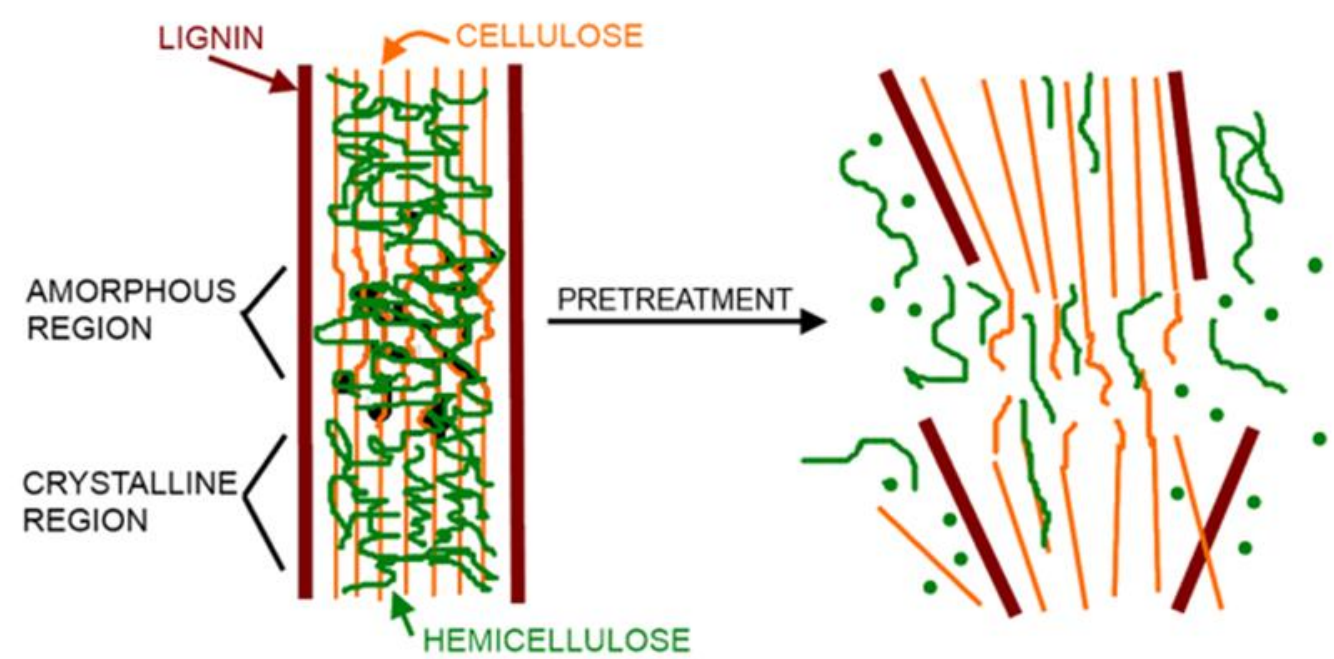

Fig. 1 Schematic representation of the role of pretreatment (Source: Muley and Boldor, 2017.)

\section{Material and Method}

\subsection{Culturing of Bacteria}

Bacillus sp. and Norcadiopsis sp., two hydrolyzing bacterial strains isolated from previous work, were cultivated in CMC agar medium (Weerasinghe, Madusanka and Manage, 2021) and incubated at room temperature $\left(28 \pm 2{ }^{\circ} \mathrm{C}\right)$ for $24 \mathrm{~h}$ (Immanuel et al., 2006). Achromobacter sp., a fermenting bacterium previously isolated (Weerasinghe, Madusanka and Manage, 2021), was cultivated in the Glucose agar medium and incubated for $24 \mathrm{~h}$ at room temperature $\left(28 \pm 2{ }^{\circ} \mathrm{C}\right.$ ) (Immanuel et al., 2006).

\subsection{Corncob Collection and Processing}

Corncobs were collected and cleaned properly using tap water. The particles then were dried in a hot air oven at $30{ }^{\circ} \mathrm{C}$ (Braid et al., 2016) and ground to a diameter of about $2 \mathrm{~mm}$ (Chen Xia and Xue, 2007).

\subsubsection{Corncob Acid Pretreatment}

Ground corncobs were pretreated with a $2 \% \mathrm{H}_{2} \mathrm{SO}_{4}$ (vol./vol.) solution, with biomass to liquid ratio of $1: 10$, subsequently autoclaved for twenty $\min$ at $121{ }^{\circ} \mathrm{C}$ (modified method of Zhang et al., 2010). The pretreated corncobs were filtered and washed with distilled water until neutralized, and washed with $50 \mathrm{mM}$ citric buffer solution after cooling at ambient temperature $\left(28 \pm 2{ }^{\circ} \mathrm{C}\right)$ ( $\mathrm{pH}$ 4.8). The residues from the pretreated corncobs then dried in a hot air oven (Kahar, Taku and Tanaka, 2010; Zhang et al., 2010).

\subsubsection{Corncob Alkaline Pretreatment}

The powdered corncobs pretreated with a $2 \% \mathrm{NaOH}$ (vol./vol.) solution and heated at $100{ }^{0} \mathrm{C}$ for $1 \mathrm{~h}$ with biomass to liquid ratio of 1:10. (Modified method of Zhang et al., 2010). The pretreated corncobs were filtered and washed with distilled water until neutralized after cooling at room temperature $\left(28 \pm 2{ }^{\circ} \mathrm{C}\right)$. The corncobs were then rinsed and dried in a hot air oven with $50 \mathrm{mM}$ citric buffer solution (pH 4.8) (Kahar, Taku and Tanaka, 2010; Zhang et al., 2010).

\subsection{Paper Waste Acid Pretreatment}

The collected paper waste was ground into fine particles less than $5 \mathrm{~mm}$ diameter. The ground paper waste was pretreated with a $2 \% \quad \mathrm{H}_{2} \mathrm{SO}_{4} \quad$ (vol./vol.) solution subsequently autoclaved at $121{ }^{\circ} \mathrm{C}$ for $30 \mathrm{~min}$ with biomass to liquid ratio of $1: 10$. The samples were removed and filtered after cooling at room temperature. The paper waste was washed with a $50 \mathrm{mM}$ citric buffer solution $(\mathrm{pH}$ 4.8) after neutralized the biomass using distilled water. Finally, the biomass was dried in a hot air oven after processing (modified method of Singh and Trivedi, 2013).

\subsubsection{Paper Waste Alkaline Pretreatment}

To the $10 \mathrm{~g}$ of pulped paper waste, $100 \mathrm{~mL}$ of $2 \% \mathrm{H}_{2} \mathrm{O}_{2}$ was added and retained at $30{ }^{\circ} \mathrm{C}$ for $8 \mathrm{~h}$. The pulped paper waste was removed after $8 \mathrm{~h}$, filtered, and rinsed with distilled water. Then pulped paper waste was pretreated with a $2 \% \mathrm{NaOH}$ (vol./vol.) solution with biomass to liquid ratio of $1: 10$ and heated at $100{ }^{\circ} \mathrm{C}$ for $1 \mathrm{~h}$. The pretreated paper waste was washed with distilled water until neutralized after cooling. The paper waste is then rinsed and dried in a hot air oven with a $50 \mathrm{mM}$ citric buffer solution (pH 4.8) (Singh and Trivedi, 2013).

\subsection{Total Cellulase Enzyme Assay for Evaluating Bacteria Saccharification of Lignocellulosic Biomass}

In $0.9 \%$ saline water, cultured hydrolysing bacterial strains Bacillus sp. and Norcadiopsis sp. were equalized separately according to $0.5 \mathrm{McF}$ arland standards. The bacteria were then inoculated in $15 \mathrm{~mL}$ of CMC broth, containing $1.2 \% \mathrm{CMC}, 1.2 \%$ acid pretreated corncobs, $1.2 \%$ alkaline pretreated corncobs, $1.2 \%$ acid pretreated paper waste $1.2 \%$ alkaline pretreated paper waste, respectively. The samples were then agitated over $72 \mathrm{~h}$ at $37^{\circ} \mathrm{C}$ at $100 \mathrm{rpm}$ (Model: Multishaker MMS, Japan). The crude extract of cellulase enzyme was prepared following centrifugation for $15 \mathrm{~min}$ in $5000 \mathrm{rpm}$ at $4{ }^{\circ} \mathrm{C}$. To remove bacterial cells, using $0.45 \mu \mathrm{m}$ syringe filters the resultant supernatant was filtered.

Then a rolled filter paper strip was inserted in the test tube to evaluate the enzyme activity. The tubes were then supplied with $0.5 \mathrm{~mL}$ of the cell-free crude enzyme solution and $1.0 \mathrm{~mL}$ of $50 \mathrm{mM}$ citric buffer solution $(\mathrm{pH}$ 
4.8), and with a paper strip submerged in the buffer. Following $60 \mathrm{~min}$ of incubation at $50{ }^{\circ} \mathrm{C}, 3.0 \mathrm{~mL}$ of dinitro salicylic acid (DNS) reagent was added. After that, all of the test tubes were immersed in water at $100{ }^{\circ} \mathrm{C}$ for $5 \mathrm{~min}$. Then test tubes were incubated in a cold water bath and $20 \mathrm{~mL}$ distilled water was added to the tubes, which were then inverted several times to mix. The absorbance of 'pulp' was measured at $540 \mathrm{~nm}$ after it settled. The total cellulase enzyme extracted from each biomass was tested (Zhang et al., 2009).

\subsection{Simultaneous Saccharification for Bioethanol Production}

Bacillus sp. and Norcadiopsis sp. were equalized separately in $0.9 \%$ saline solution using 0.5 McFarland standards. The $20 \%$ of the bacteria suspension inoculated in $100 \mathrm{~mL}$ of CMC broth containing $1.2 \% \mathrm{CMC}$, alkaline and acid pretreated corncobs, and alkaline as well as acid pretreated paper wastes. In the shaking incubator, it was then incubated for $72 \mathrm{~h}$ at $37^{\circ} \mathrm{C}$ at $100 \mathrm{rpm}$. The hydrolyzed sample was centrifuged for $15 \mathrm{~min}$ at $5000 \mathrm{rpm}$ at $4^{\circ} \mathrm{C}$ after $72 \mathrm{~h}$.

The cell-free crude enzyme sample was mixed with $100 \mathrm{~mL}$ of glucose-free glucose broth medium and inoculated with $20 \%$ of a selected fermented bacterial, equalized in $0.9 \%$ saline solution according to 0.5 McFarland standards. In the shaking incubator, it was then incubated for $72 \mathrm{~h}$ at $37^{\circ} \mathrm{C}$ at $100 \mathrm{rpm}$.

\subsection{Bioethanol Production Primary Screening}

Selected hydrolyzing bacterial strains were equalized in $0.9 \%$ saline solution, according to 0.5 McFarland standards. Afterwards, inoculated $1.0 \mathrm{~mL}$ of CMC broth medium containing $1.2 \%$ CMC, alkaline pretreated corncobs, pretreated acid corncobs, alkaline pretreated paper waste, and acid pretreated paper waste order. The samples then shaken for $72 \mathrm{~h}$ at $37^{\circ} \mathrm{C}$ with 100 rotations per minute (Model: Multishaker MMS, Japan). The digested sample was centrifuged for $15 \mathrm{~min}$ at $5000 \mathrm{rpm}$ at $4{ }^{\circ} \mathrm{C}$ after $72 \mathrm{~h}$. The crude enzyme extract was added to glucose-free glucose broth medium in boiling tubes containing Durham tubes and inoculated with Achromobacter sp. according to 0.5 McFarland standards. The bacteria were again cultured at room temperature for $24 \mathrm{~h}$, and gas production was measured (modified method of Dung and Huyuh, 2013).

\subsection{Bioethanol Production Secondary Screening}

To analyse the ethanol percentage in fermented broth, a multi-dimensional GCMS (Agilent Technologies, model: GC system-7890 A, MS system-5975 C) was used with combination to system automation and data acquisition software (ChemStation) and a DB $225 \mathrm{~ms}$ capillary column (5\% phenyl methylsiloxane, , length $30 \mathrm{~m}$, thickness 0.25 $\mathrm{M}$, and diameter $0.25 \mathrm{~mm}$, Agilent). The general run parameters include injector in $200{ }^{\circ} \mathrm{C}$, oven temperature program of $40^{\circ} \mathrm{C}$ initials, five min hold with $10^{\circ} \mathrm{C} / \mathrm{min}$ and then $43{ }^{\circ} \mathrm{C}$ final and GC-grade $\mathrm{He}$ as carrier gas at 0.5 $\mathrm{mL} / \mathrm{min}$. flow and exactly 0.69481 psi pressure was maintained. Between 35 and 550 range, the ratio of mass to charge $(\mathrm{m} / \mathrm{z})$ was set. The energy of electron ionization of $70 \mathrm{eV}$ was set. Auto tuning of the MS detector was done on a regular basis.

\subsubsection{Conditions of SPME (Solid phase micro-extraction)}

Before the first use, SPME fiber was conditioned by storing it at $200{ }^{\circ} \mathrm{C}$ for $20 \mathrm{~min}$. The SPME conditions for GCMS with an auto-sampler were then followed. To a screw-caped vial of $25 \mathrm{~mL}$ with a silicon septum with polytetrafluoroethylene (PTFE), a $3.0 \mathrm{~mL}$ aliquot of the broth was transferred. Before SPME extraction, the vial was shaken for $5 \mathrm{~min}$ and afterwards kept at room temperature overnight. After that, via the screw cap's septum the SPME fiber was inserted into the vial. The SPME fiber was exposed to the vial for $10 \mathrm{~min}$. Then carefully the SPME fiber was removed from the vial and for the analysis after every extraction the fiber was put into GC injection port. A standard curve based on the responses of MS detector to selected ion monitoring (SIM) for a known concentration of ethanol standard was used to determine the ethanol concentration in samples.

\subsubsection{Ethanol-Diesel Emulsion Preparation}

By mixing ethanol with diesel, it could be used as automotive fuel or as a fuel extender. E2 is a blend of $2 \%$ ethanol and 98\% diesel, E5 is a blend of 5\% ethanol and $95 \%$ diesel, E7 is a blend of $7 \%$ ethanol and 93\% diesel, and E10 is a blend of $10 \%$ ethanol and $90 \%$ diesel. Anhydrous ethanol was mixed with Ceylon Petroleum Cooperation's (Ceypetco) Grade 02 Auto Diesel at the percentages stated above to produce the ethanol-diesel emulsions. An electromagnetic stirring machine (Model: IKA®C-MAG HS 7) was used to prepare emulsions evenly for $30 \mathrm{~min}$. Then an ultrasonic bath sonication machine (Model: Transsonic 820) was used to combine these for 15 min (Debnath, Sahoo and Saha, 2013).

\subsection{Physico-chemical Characterization of Ethanol-Diesel Emulsions}

Ceypetco refinery laboratory tested the density, viscosity, flash point, sulfur content, and lubricity of the emulsions to compare the ASTM D4806 and Ceypetco specifications for suitability of the blends for the replacement of diesel in CI engines without any engine modifications.

\section{Result and Discussion}

The scenario of growing demands, decreasing fossil fuel reserves, and increased pollution through fossil fuel combustion has raised awareness of researchers worldwide on the need to discover environmentally friendly alternative energies, particularly transportation fuels (Gupta et al, 2019). Bioethanol has been identified as a competitive liquid fuel that can use as a transportation fuel in this scenario. The existing research focused on the production of second-generation bioethanol using lignocellulosic biomass as a possible alternative to the future energy crisis.

Since it influences the efficiency of cellulose bioconversion into fermentable sugars, pretreatment is very essential in the processing of second-generation 
bioethanol (Mafa et al., 2020). In the current study, corncobs and paper waste were subjected for chemical and mechanical pretreatments. Grinding was used as a mechanical pretreatment first, followed by acid and alkaline pretreatments as chemical pretreatments. Hence, the pretreatment process destroys the corncob residues physical structure to a certain degree and become loose and porous, it expected that enzyme resistance to corncob residues was considerably reduced (Yang et al., 2021). Grinding reduces the total size of biomass while expanding the accessible surface area.

Consequently, the affinity between cellulose and enzymes is enhanced, the compact structure of lignocellulose disassembled, and the rate of hydrolysis is improved. (Zoghlami and Pas, 2019). Biomass recalcitrance is disrupted via acid and alkaline pretreatment reactions that enhance hydrolysis (Baruah et al., 2018). Acid pretreatment cleaves the glucosidic bonds in lignocellulosic matrix and mainly solubilises the hemicellulose. Also, it solubilises a trace amount of the lignin and enhance further enzymatic attack on cellulose (Woiciechowski et al., 2020). Alkaline pretreatment solubilize lignin more efficiently and a tiny amount of the hemicellulose, reducing cellulose crystallinity (Tsegaye, Balomajumder and Roy, 2019; Restiawaty et al., 2020; Woiciechowski et al., 2020).

\subsection{Total Cellulase Enzyme Assay for Evaluating Bacterial Saccharification of Lignocellulosic Biomass}

Chemical hydrolysis by acids or biological hydrolysis using enzymes derived from different microorganisms are the most common methods for hydrolysis or saccharification of pretreated lignocellulosic biomass (Sharma, Larroche and Dussap, 2020). Chemical hydrolysis is the most common and rapid approach for hydrolysis (Wan et al., 2018). However, many microorganisms have been identified as potential hydrolysing microorganisms like Aspergillus niger, Pseudomonas aeruginosa, Trichoderma reesei, Bacillus subtilis, Streptomyces coelicolor etc. (Ojewumi et al., 2018; Efeovbokhan et al., 2019; Singhvi and Gokhale, 2019). As a consequence, the focus of this study had been on biological hydrolysis, using two bacterial strains, Bacillus sp. and Norcadiopsis sp. which were isolated from a previous study by Weerasinghe, Madusanka and Manage, (2021).

The total cellulase enzyme assay was used to determine the saccharification of different pretreated lignocellulosic biomass by those selected bacteria. The crude enzyme extract was prepared upon saccharification of pretreated acid corncobs obtained the highest glucose concentration of $0.051 \pm 0.015 \mathrm{mg} / \mathrm{mL}$. In contrast, alkaline pretreated corncobs resulted in the lowest glucose concentration of $0.011 \pm 0.015 \mathrm{mg} / \mathrm{mL}$. Total cellulase enzyme tests were done by employing crude enzyme extract saccharification of alkaline pretreated paper waste, acid pretreated paper waste, and CMC yielded glucose concentrations of $0.048 \pm 0.015 \mathrm{mg} / \mathrm{ml}, 0.047 \pm 0.015$ $\mathrm{mg} / \mathrm{mL}$, and $0.050 \pm 0.015 \mathrm{mg} / \mathrm{mL}$ (Figure 2) respectively. Bacillus sp. appears to be particularly effective at hydrolytic pretreated corncobs, depending on these results.

Following saccharification of acid pretreated paper waste, crude enzyme extract had the highest glucose concentration of $0.044 \pm 0.005 \mathrm{mg} / \mathrm{mL}$, while crude enzyme extract prepared with alkaline pretreated corncobs had the lowest glucose concentration of $0.029 \pm 0.005 \mathrm{mg} / \mathrm{mL}$. Total cellulase enzyme tests were done for crude enzyme extract generated following saccharification of acid pretreatment corncobs, alkaline pretreated paper waste. CMC with Norcadiopsis sp. give glucose concentrations of $0.031 \pm 0.005 \mathrm{mg} / \mathrm{mL}, 0.038 \pm 0.005 \mathrm{mg} / \mathrm{mL}$, and $0.033 \pm 0.005$ $\mathrm{mg} / \mathrm{mL}$, respectively (Figure 3 ). The results revealed that Norcadiopsis sp. are highly effective at hydrolytic acid-pretreated paper waste.

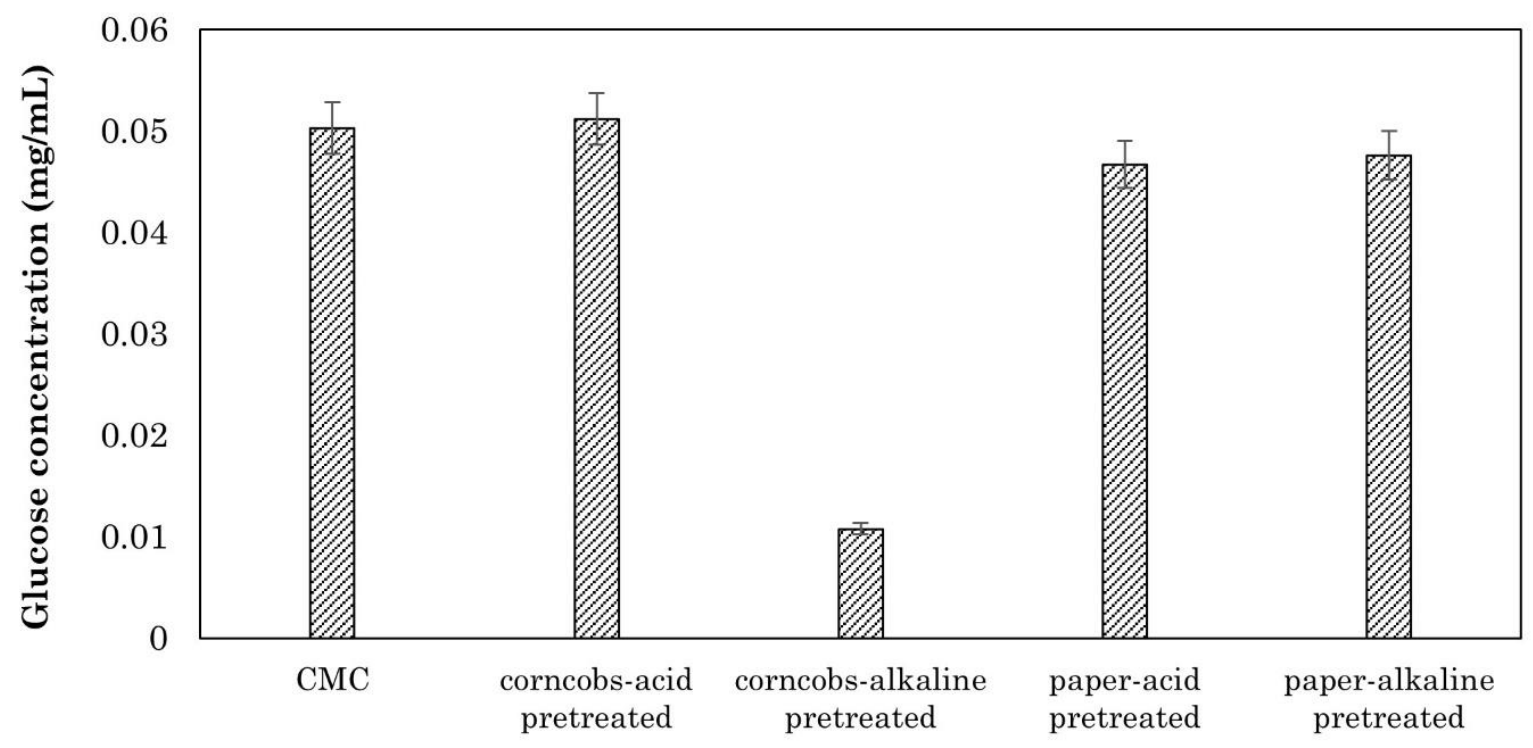

Type of biomass

Fig. 2 Total glucose concentrations following $1 \mathrm{~h}$ incubation at $50^{\circ} \mathrm{C}$ with cell free enzyme filtrates prepared after 3 days of incubation of different biomasses with Bacillus sp. 




\section{Type of biomass}

Fig 3. Total glucose concentrations following $1 \mathrm{~h}$ incubation at $50{ }^{\circ} \mathrm{C}$ with cell-free enzyme filtrates prepared after 3 days of incubation with different biomasses using Norcadiopsis sp.

The pretreated biomass and commercially available cellulosic biomass CMC digested separately using pure cultures of isolated Bacillus sp. and Norcadiopsis sp. Bacillus sp. produced the highest glucose concentrations for pretreated acid corncobs when comparing to both bacterial strains. In the saccharification of alkaline pretreated corncobs, both bacterial strains have had the lowest glucose contents. Even though CMC is a readily available cellulosic biomass, the glucose concentration generated is less than that of several pretreated biomass, showing that lignocellulosic biomass pretreatment significantly impacts increased saccharification rates.

\subsection{Primary Screening for Bioethanol Production}

Simultaneous Saccharification and Fermentation (SSF) is a well-known process that involves combining the enzymatic hydrolysis of cellulose into glucose with the fermentation of glucose into ethanol in the same environment (Chandel et al., 2013; Sewsynker and Kana, 2018). Weerasinghe, Madusanka and Manage, (2021) described that in cellulose hydrolysis and sugar fermentation, the SSF process gives the highest ethanol percentage than the Separate Enzymatic Hydrolysis and Fermentation (SHF). Also Sudiyani et al., (2016) had stated that ethanol production is higher in SSF process than in SHF process.

As a consequence, bioethanol produced using the SSF process in the current study. Bacillus sp. and Norcadiopsis sp. hydrolyzed the pretreated biomass separately, and the cell-free crude enzyme extract was fermented using Achromobacter sp. Though Saccharomyces cerevisiae is the most studied and widely used fermenting microbe in ethanol production, Zymomonas mobilis is the second most studied fermenting organism (Bai, Anderson and Moo-Young, 2008; Sharma and Sharma, 2018), Achromobacter sp. was used for sugar fermentation in this study.

In primary screening all samples, including saccharification of acid pretreated corncobs, alkaline pretreated corncobs, alkaline pretreated paper waste, acid pretreated paper waste, and CMC by Bacillus sp. and Norcadiopsis sp. and then fermented by Achromobacter sp. following SSF process showed production of gas in Durham tubes which confirms the bioethanol production (Figure 4). 


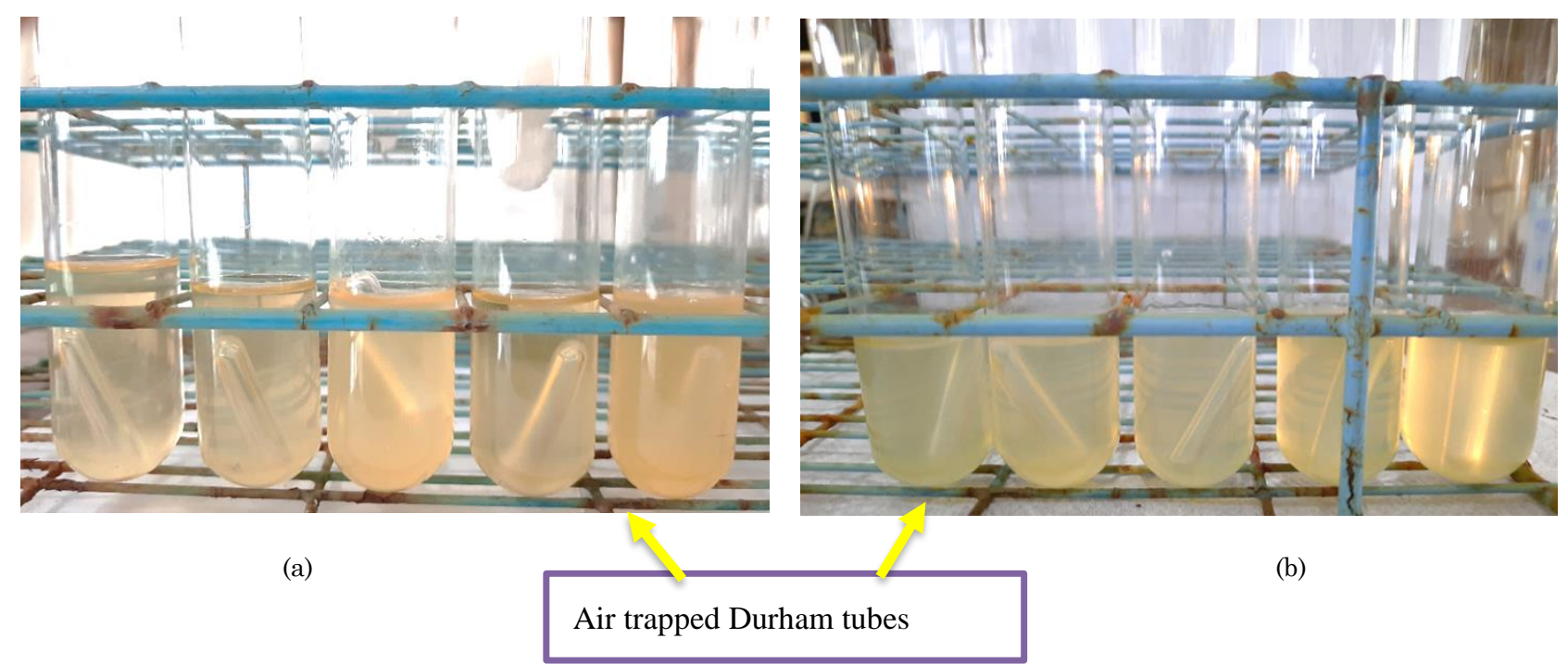

Fig. 4. Primary screening of ethanol production via hydrolysis of biomass by a). Bacillus sp., b). Norcadiopsis sp. for $72 \mathrm{~h}$ and fermentation by Achromobacter sp. for $48 \mathrm{~h}$.

\subsection{Secondary Screening for Bioethanol Production}

Solid phase micro extraction (SPME) has been combined with GCMS to quantify ethanol production in the SSF bioprocess. The non-volatile and volatile products in liquid samples are determined using the GCMS method. Direct insertion of samples containing water, sugars, or other non-volatile components, on the other side, can allow the GC instrument to become blocked (Onuki et al., 2016). Because fermented broth samples contain an amount of moisture, using the SPME method combined with GCMS captures the vapor phase over the sample and produces reliable data. SPME is a simple, solvent-free method for estimating a vast number of compounds at low concentrations. The highest values of the chromatogram show the most abundant fragments for ethanol, which were 31 and $45 \mathrm{~m} / \mathrm{z}$, respectively, according to the mass spectrum of ethanol by Weerasinghe, Madusanka and Manage, (2021). As a result, $45 \mathrm{~m} / \mathrm{z}$ was selected in the ongoing study to assess ethanol concentration in the broth medium, further employing SIM mode.

Table 1 shows the ethanol percentages obtained from the SSF process of different lignocellulosic biomass through quantification of selected $45 \mathrm{~m} / \mathrm{z}$ ion count by operating MS in SIM mode. The SIM mode analysis revealed that alkaline pretreated paper waste hydrolyzed by Bacillus sp. yielded the highest ethanol percentage of $0.734 \pm 0.154$. In contrast, pretreated acid corncob hydrolyzed by Bacillus sp. produced the second-highest ethanol percentage of $0.726 \pm 0.154$. Alkaline pretreatment corncob digested by Norcadiopsis sp. yielded the lowest concentration of $0.155 \pm 0.154$. These results indicate that paper waste is a promising feedstock for the secondgeneration bioethanol production. According to literature, in Sri Lanka, a considerable percentage of paper waste consider as solid waste without any proper usage (75-80\%) and hence recycling is still at a preliminary level (Wipulasena, 2018). Therefore in Sri Lanka, paper waste is a promising feedstock.

Table 1

The ethanol percentages obtained from different lignocellulosic biomass via SSF process. The fermentation was done using Achoromobacter sp.

\begin{tabular}{cccc}
\hline Type of biomass & Pretreatment method & Hydrolysing bacteria & Ethanol percentage \\
\hline Corncob & Acid Pretreatment & Bacillus sp. & $0.726 \pm 0.154 \%$ \\
Corncob & Acid Pretreatment & Norcadiopsis sp. & $0.587 \pm 0.154 \%$ \\
Corncob & Alkaline Pretreatment & Bacillus sp. & $0.564 \pm 0.154 \%$ \\
Corncob & Alkaline Pretreatment & Norcadiopsis sp. & $0.155 \pm 0.154 \%$ \\
Paper waste & Acid Pretreatment & Bacillus sp. & $0.657 \pm 0.154 \%$ \\
Paper waste & Acid Pretreatment & Norcadiopsis sp. & $0.599 \pm 0.154 \%$ \\
Paper waste & Alkaline Pretreatment & Bacillus sp. & $0.734 \pm 0.154 \%$ \\
Paper waste & Alkaline Pretreatment & Norcadiopsis sp. & $0.627 \pm 0.154 \%$ \\
CMC & - & Bacillus sp. & $0.512 \pm 0.154 \%$ \\
CMC & - & Norcadiopsis $\mathrm{sp}$. & $0.551 \pm 0.154 \%$ \\
\hline
\end{tabular}




\subsection{Ethanol-Diesel Emulsion Preparation}

Since it found that ethanol-diesel blends were technically appropriate for existing diesel engines, bioethanol has attracted worldwide attention as a partial or full substitute for fossil (Deshavath, Veeranki and Goud, 2019). It primarily used as a fuel by blending ethanol with diesel (Hansen, Zhang and Lyne, 2005). As a result, E2, E5, E7, and E10 ethanol-diesel blends were produced in the current study, with $2 \%, 5 \%, 7 \%$, and $10 \%$ ethanol blended with 98\%, 95\%, 93\%, and 90\% diesel, respectively. As many significant modifications in ethanoldiesel blends with higher ethanol percentages are needed to adapt the parameters required for conventional diesel fuel, lower ethanol percentages are more promising (Kuszewski, Jaworski and Ustrzycki, 2017).

Though the use of ethanol-diesel blends as a fuel is a simple application, the drawback is that the ethanol is less soluble in diesel (Parthasarathi, Gowri and Saravanan, 2014; Pereira and Rangel, 2020). According to Hajba et al., (2011) the solubility of ethanol in diesel fuel is largely influenced by the water content, temperature, the diesel fuel's hydrocarbon composition, and additives. In any case, ethanol was partially miscible with diesel in this study.

Initial turbidity, interface appearance, and displacement of the interface until equilibrium described by Lapureta, Armas and Garcia-Contreras (2007) in phase separation of a mixture of ethanol and diesel. When ethanol was added to diesel, these three stages were observed. These samples were converted directly into a turbid solution with no phase separation at first. Then, in the superior part of the mixture, a more transparent, less dense phase of bioethanol was formed, while a lower degree remained turbid. The length of the bioethanol phase increased in the third stage, and the interface shifted towards the inferior part until it reached a steady, and the diesel phase became transparent. Phase separation has seen in ethanol-diesel blends as the ethanol percentage increased.

\subsection{Analysis of Physico-chemical Properties of Ethanol- Diesel Emulsions}

The results of tests evaluating lubricity, Calorific value, viscosity, density, flash point and sulfur content of prepared E2, E5, E7, and E10 emulsions are compared with ASTM D4806 and Ceypetco standards (Table 2).

It's critical to compare the properties of the prepared emulsions to ASTM D4806 and Ceypetco specifications to determine whether they'll be suitable for replacing diesel in CI engines without any engine modifications. The ASTM D4806 is the standard specification for denatured fuel ethanol for blending with gasoline for use as automotive spark-ignition engine fuel. Anhydrous denatured fuel ethanol designed to be blended at $1-15 \%$ by volume with unleaded or leaded gasoline for use as automobile spark-ignition engine fuel is nominally covered by this specification (www.astm.org/Standards/D4806). This ASTM D4806 standard is mainly concerned with quality parameters such as ethanol concentration, water content, inorganic chloride, acidity, and sulfur content, among many others. On the other hand, the maximum sulfur content limit, is substantially lower than the sulfur content of prepared diesel-ethanol blends.

Lubricity, density, viscosity, calorific value and sulfur content of the blends were within the range per Ceypetco Grade 02 Auto Diesel fuel specifications and the recorded values are compatible. However, when the flashpoint was accounted for, it was much lower than the prescribed limits. The recorded qualities must be evaluated to determine the possible commercial usage of ethanol-diesel blends in diesel engines without engine modifications, as engine adjustments are substantial and expensive.

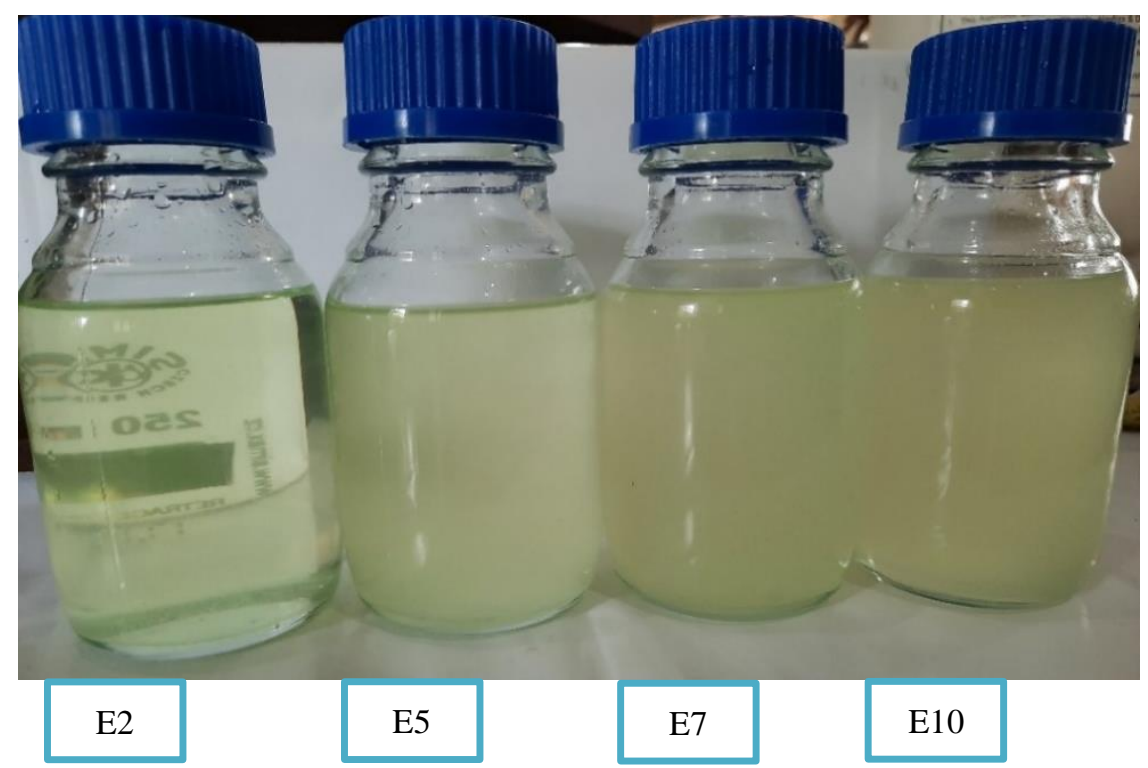

Fig 5. Ethanol-diesel emulsions (E2 - 2\% ethanol+98\% diesel, E5 - 5\% ethanol+95\% diesel, E7 - 7\% ethanol+93\% diesel, E10 - 10\% ethanol+90\% diesel). 
Table 2

The fuel properties of ethanol-diesel emulsions. When compared to Auto Diesel Grade 02 specifications.

\begin{tabular}{ccccccc}
\hline Property/Test & Method - & E2 & E5 & E7 & E10 & Lanka Auto Diesel \\
& ASTM & & & & & \\
\hline Density $\left(@ 15{ }^{\circ} \mathrm{C} \mathrm{kg} / \mathrm{m}^{3}\right)$ & D 1298 & 827.7 & 827.4 & 827.0 & 826.5 & $820-860^{*}$ \\
Lubricity (HFRR wear scar dia. $\left.@ 60^{\circ} \mathrm{C}\right)$ & D 6079 & 370 & 390 & 420 & 430 & NS \\
Sulfur content (mg/kg) & D 4294 & 223 & 224 & 217 & 217 & Max $3000^{*}$ \\
Viscosity (@40 $\left.{ }^{\circ} \mathrm{C}, \mathrm{cst}\right)$ & D 445 & 3.740 & 3.160 & 2.902 & 2.386 & $1.5-5.0^{*}$ \\
Flash point ( $\left.{ }^{\circ} \mathrm{C}\right)$ & D 93 & 35.0 & $<30.0$ & $<30.0$ & $<30.0$ & Min $60^{*}$ \\
Calorific value (Gross Kcal/kg) & D 240 & 11321.0 & 11172.0 & 11034.0 & 11139.0 & Min $10500^{*}$ \\
\hline
\end{tabular}

* - According to Ceypetco Product Specifications for Auto diesel (www.ceypetco.gov.lk); NS - Not specified

\section{Recommendations}

The low ethanol yields from bacterial pathways can be overcome by genetically modifying the bacteria to improve hydrolysis rates and fermentation. To increase ethanol production, combined optimization of the pretreatment of lignocellulosic biomass is also recommended.

The main disadvantage of reduced ethanol miscibility in diesel can be overcome by using co-solvents and emulsifiers. Investigating more efficient and low cost emulsifiers and co-solvents is in need. Hence reduced flashpoint is a great safety concern further studies are compulsory to enhance flashpoint in ethanol-diesel blends. Deficiencies associated with higher ethanol-diesel blends should also be addressed because it is crucial since higher ethanol-diesel blends can greatly reduce the diesel dependency. The engine performance of the prepared ethanol-diesel blends must be evaluated inorder to study the practical usage of ethanol-diesel blends.

\section{Conclusions}

The use of lignocellulosic biomass to generate secondgeneration bioethanol provides a long-term answer to the future energy dilemma. Bacillus sp. has a maximum biomass saccharification capability than Norcadiopsis sp., based on the results of a total cellulase enzyme assay for assessing bacterial saccharification of lignocellulosic biomass. The hydrolysis rates and ethanol yields of lignocellulosic biomass were enhanced when pretreated, because ethanol yields from SSF of lignocellulosic biomass are higher than SSF of CMC. According to the results, simultaneous Saccharification and Fermentation using alkaline pretreated paper waste hydrolyzed by Bacillus sp. and fermented by Achromobacter sp. the highest ethanol percentage is $0.734 \pm 0.154$. As a consequence, paper waste does have a high potential as a feedstock to second-generation bioethanol production.

Blending ethanol with commercial diesel fuel is a widely established method of reducing pollutants, reducing greenhouse gas emissions, and prolonging current fossil fuels' life. The results of the physicochemical characteristic assessment of the prepared ethanol-diesel emulsions showed that all of the project's existence, except for flashpoint, met Ceypetco specifications, implying that ethanol-diesel blends could be used in CI engines without modification. The results show that ethanol-diesel emulsions with reduced emulsions could be a viable solution to the looming energy crisis.

\section{References}

Aditiya, H.B., Mahlia, T.M.I., Chong, W.T., Nur, H. and Sebayang, A.H. (2016). Second generation bioethanol production: A critical review. Renewable and sustainable energy reviews, 66, 631-653; doi.org/10.1016/j.rser.2016.07.015

Al-Esawi, N., Al Qubeissi, M. and Kolodnytska, R. (2019). The impact of biodiesel fuel on ethanol/diesel blends. Energies, 12(9), 1804; doi.org/10.3390/en12091804

Baruah, J., Nath, B.K., Sharma, R., Kumar, S., Deka, R.C., Baruah, D.C. and Kalita, E. (2018). Recent trends in the pretreatment of lignocellulosic biomass for value-added products. Frontiers in Energy Research, 6, 141; doi.org/10.3389/fenrg.2018.00141

Bai, F.W., Anderson, W.A. and Moo-Young, M. (2008). Ethanol fermentation technologies from sugar and starch feedstocks. Biotechnology advances, 26(1), 89-105; doi.org/10.1016/j.biotechadv.2007.09.002

BP Statistical Review of World Energy (2020). 69th edition, 1-68.

Braide, W., Kanu, I.A., Oranusi, U.S. and Adeleye, S.A. (2016). Production of bioethanol from agricultural waste. Journal of fundamental and Applied Sciences, 8(2), 372-386; doi.org/10.4314/jfas.v8i2.14

Branco, R.H., Serafim, L.S. and Xavier, A.M. (2019). Second generation bioethanol production: on the use of pulp and paper industry wastes as feedstock. Fermentation, 5(1), 4; doi.org/10.3390/fermentation5010004

Chandel, A.K., Chan, E.S., Rudravaram, R., Narasu, M.L., Rao, L.V. and Ravindra, P. (2013). Economics and environmental impact of bioethanol production technologies: an appraisal. Biotechnology and molecular $\begin{array}{llll}\text { biology review, } & \text { 2(1), }\end{array}$ doi.org/10.5897/BMBR2007.0002

Chen, M., Xia, L. and Xue, P. (2007). Enzymatic hydrolysis of corncob and ethanol production from cellulosic hydrolysate. International Biodeterioration \& Biodegradation, $\quad 59(2), \quad 85-89$; doi.org/10.1016/j.ibiod.2006.07.011

Debnath, B.K., Sahoo, N. and Saha, U.K. (2013). Adjusting the operating characteristics to improve the performance of an emulsified palm oil methyl ester run diesel engine. Energy Conversion and Management, 69, 191-198; doi.org/ 10.1016/J.ENCONMAN.2013.01.031

Deshavath, N.N., Veeranki, V.D. and Goud, V.V. (2019). Lignocellulosic feedstocks for the production of bioethanol: availability, structure, and composition. In Sustainable Bioenergy, 1-19. Elsevier; doi.org/10.1016/B978-0-12817654-2.00001-0

Dung, N.T.P. and Huynh, P.X. (2013). Screening Thermo-and Ethanol Tolerant Bacteria for Ethanol Fermentation. American Journal of Microbiological Research, 1(2), 25-31; doi.org/10.12691/AJMR-1-2-3

Efeovbokhan, V.E., Egwari, L., Alagbe, E.E., Adeyemi, J.T. and Taiwo, O.S. (2019). Production of bioethanol from hybrid cassava pulp and peel using microbial and acid hydrolysis. 

$\begin{array}{lccc}\text { BioResources, } & \text { 14(2), } & \text { 2596-2609; } \quad \text { doi.org/ } \\ \text { 10.15376/biores.14.2.2596-2609 }\end{array}$

Farida, I., Syamsu, K., and Rahayuningsih, M. (2015). Direct Bioethanol Production from Breadfruit Starch (Artocarpus communis Forst) by Engineered Simultaneous Saccharification and Fermentation (ESSF) using Microbes Consortium. International Journal of Renewable Energy Development, 4(1), 25-31; doi.org/10.14710/ijred.4.1.25-31

Gao, Z., Lin, S., Ji, J. and Li, M. (2019). An experimental study on combustion performance and flame spread characteristics over liquid diesel and ethanol-diesel blended fuel. Energy, 170, 349-355; doi.org/10.1016/j.energy.2018.12.130

Gupta, R., Yadav, G., Kumar, G., Yadav, A., Saini, J.K. and Kuhad, R.C. (2019). Second generation bioethanol production: the state of art. Sustainable approaches for biofuels production technologies, 121-146; doi.org/10.1007/978-3-319-94797-6_8

Hagos, F.Y., Ali, O.M., Mamat, R. and Abdullah, A.A. (2017). Effect of emulsification and blending on the oxygenation and substitution of diesel fuel for compression ignition engine. Renewable and Sustainable Energy Reviews, 75, 1281-1294; doi.org/10.1016/j.rser.2016.11.113

Hajba, L., Eller, Z., Nagy, E. and Hancsok, J. (2011). Properties of diesel-alcohol blends. Hungarian Journal of Industry and Chemistry, 39(3), 349-352; doi.org/10.1515/446

Halder, P., Azad, K., Shah, S. and Sarker, E. (2019). Prospects and technological advancement of cellulosic bioethanol ecofuel production. In Advances in eco-fuels for a sustainable environment, 211-236; doi.org/10.1016/B978-0-08-1027288.00008-5

Hansen, A.C., Zhang, Q. and Lyne, P.W. (2005). Ethanol-diesel fuel blends-a review. Bioresource technology, 96(3), 277285; doi.org/10.1016/j.biortech.2004.04.007

Immanuel, G., Dhanusha, R., Prema, P. and Palavesam, A. (2006). Effect of different growth parameters on endoglucanase enzyme activity by bacteria isolated from coir retting effluents of estuarine environment. International Journal of Environmental Science \& $\begin{array}{llll}\text { Technology, } & \text { vol.3. } & \text { no.1, } & .25-34 ;\end{array}$ doi.org/10.1007/BF03325904

Jayasekara, S.K., Abayasekara, C.L. and Ratnayake, R.R. (2019). Efficient Microorganisms for Bioethanol Production from the Natural Environment of Sri Lanka. In Proceedings of International Research Symposium of Uva Wellassa University; doi.org/10.13140/RG.2.2.13363.25120

Jayathilaka, M.G.L.W., Henagamage, A.P., Peries, C.M. and Seneviratne, G. (2018). Enhancement of Cellulolytic Activity through Biofilm Action for Bioethanol Production. In Proceedings of International Research Symposium of Uva Wellassa University

Kahar, P., Taku, K. and Tanaka, S. (2010). Enzymatic digestion of corncobs pretreated with low strength of sulfuric acid for bioethanol production. Journal of bioscience and bioengineering, $\quad 110(4), \quad 453-458$; doi.org/10.1016/j.jbiosc.2010.05.002

Kularathne, I.W., Rathneweera, A.C., Kalpage, C.S., Rajapakshe,S. and Gunathilaka, C.A., (2020). Optimization and kinetic parameter estimation of bioethanol production from freely available Sri Lankan fruits in batch fermentation. Ceylon Journal of Science, 49(3), 283-291; doi.org/10.4038/cjs.v49i3.7779

Kumari, D. and Singh, R. (2018). Pretreatment of lignocellulosic wastes for biofuel production: a critical review. Renewable and Sustainable Energy Reviews, 90, 877-891; doi.org/10.1016/j.rser.2018.03.111

Kuszewski, H., Jaworski, A. and Ustrzycki, A. (2017). Lubricity of ethanol-diesel blends-Study with the HFRR method. Fuel, 208, 491-498; doi.org/10.1016/j.fuel.2017.07.046

Lapuerta, M., Armas, O. and Garcia-Contreras, R. (2007). Stability of diesel-bioethanol blends for use in diesel engines. Fuel, 86(10-11), 1351-1357; doi.org/10.1016/j.fuel.2006.11.042
Lizunkov, V. (2018). Population of the world and regions as the principal energy consumer. International Journal of Energy Economics and Policy, 2018, 8(3), 250-257.

Loow, Y.L., Wu, T.Y., Jahim, J.M., Mohammad, A.W. and Teoh, W.H. (2016). Typical conversion of lignocellulosic biomass into reducing sugars using dilute acid hydrolysis and alkaline pretreatment. Cellulose, 23(3), 1491-1520; doi.org/10.1007/s10570-016-0936-8

Madusanka, D.A.T. and Manage, P.M. (2018). Potential utilization of Microcystis Sp. for biodiesel production; Green Solution for Future Energy Crisis. Asian Journal of Microbiology Biotech. Enironmental. Science, 20(2), 506512.

Mafa, M., Malgas, S., Bhattacharya, A., Rashamuse, K. and Pletschke, B.I. (2020). The effects of alkaline pretreatment on agricultural biomasses (corn cob and sweet sorghum bagasse) and their hydrolysis by a termite-derived enzyme cocktail. Agronomy, 10(8), 1211 ; doi.org/doi.org/10.3390/agronomy10081211

Mat Aron, N.S., Khoo, K.S., Chew, K.W., Show, P.L., Chen, W.H. and Nguyen, T.H.P. (2020). Sustainability of the four generations of biofuels-A review. International Journal of Energy Research, 44(12), 9266-9282; doi.org/10.1002/er.5557

Muley, P. and Boldor, D. (2017). Advances in biomass pretreatment and cellulosic bioethanol production using microwave heating. Proceedings of SEEP. 27-30; doi.org/10.18690/978-961-286-048-6.18

Nair, R.B., Lennartsson, P.R. and Taherzadeh, M.J. (2017). Bioethanol production from agricultural and municipal wastes. In Current developments in biotechnology and bioengineering, 157-190; doi.org/10.1016/B978-0-44463664-5.00008-3

Odziemkowska, M., Matuszewska, A. and Czarnocka, J. (2016). Diesel oil with bioethanol as a fuel for compression-ignition engines. Applied Energy, 184, 1264-1272; doi.org/10.1016/j.apenergy.2016.07.069

Ojewumi, M.E., Obielue, B.I., Emetere, M.E., Awolu, O.O. and Ojewumi, E.O. (2018). Alkaline pre-treatment and enzymatic hydrolysis of waste papers to fermentable sugar. Journal of Ecological Engineering, 19(1), 211-217; doi.org/10.12911/22998993/79404

Onuki, S., Koziel, J.A., Jenks, W.S., Cai, L., Rice, S. and van Leeuwen, J. (2016). Optimization of extraction parameters for quantification of fermentation volatile by-products in industrial ethanol with solid-phase microextraction and gas chromatography. Journal of the Institute of Brewing, 122(1), 102-109; doi.org/10.1002/jib.297

Parthasarathi, R., Gowri, S. and Saravanan, C.G. (2014). Effects of ethanol-diesel emulsions on the performance, combustion and emission characteristics of DI diesel engine. American Journal of Applied Sciences, 11(4), 592; doi.org/10.3844/ajassp.2014.592.600

Pereira, R.G. and Rangel, I.R. (2020). An investigation of the performance of an ignition compression engine using ethanol-butanol-diesel mixtures. International Journal of Oil, Gas and Coal Technology, 25(2), 184-201; doi.org/10.1504/IJOGCT.2020.109443

Prasad, R.K., Chatterjee, S., Mazumder, P.B., Gupta, S.K., Sharma, S., Vairale, M.G., Datta, S., Dwivedi, S.K. and Gupta, D.K. (2019). Bioethanol production from waste lignocelluloses: A review on microbial degradation potential. Chemosphere, 231, 588-606; doi.org/ 10.1016/j.chemosphere.2019.05.142

Rastogi, M. and Shrivastava, S. (2017). Recent advances in second generation bioethanol production: an insight to pretreatment, saccharification and fermentation processes. Renewable and Sustainable Energy Reviews, 80, 330-340; doi.org/ 10.1016/j.rser.2017.05.225

Raud, M., Kikas, T., Sippula, O. and Shurpali, N.J. (2019). Potentials and challenges in lignocellulosic biofuel production technology. Renewable and Sustainable Energy 
Reviews, 111, 44-56; doi.org/10.1016/j.rser.2019.05.020

Restiawaty, E., Gani, K.P., Dewi, A., Arina, L.A., Kurniawati, K.I., Budhi, Y.W., and Akhmaloka (2020). Bioethanol Production from Sugarcane Bagasse using Neurospora intermedia in an Airlift Bioreactor. International Journal of Renewable Energy Development, 9(2), 247-253; doi.org/10.14710/ijred.9.2.247-253

Senarathna, D.B.G.M., Rupasinghe, C.P. and Bandara, W.B.M.A.C. (2019). Bioethanol Production from Lignocellulosic Materials. In Proceedings of EdHat International Research Conference on Technology and Innovation (IRCTECiN).

Sewsynker-Sukai, Y. and Kana, E.G. (2018). Simultaneous saccharification and bioethanol production from corn cobs: Process optimization and kinetic studies. Bioresource technology, 262, 32-41; doi.org/10.1016/j.biortech.2018.04.056

Sharma, B., Larroche, C. and Dussap, C.G. (2020). Comprehensive assessment of $2 \mathrm{G}$ bioethanol production. Bioresource technology, 313, 123-630; doi.org/10.1016/j.biortech.2020.123630

Sharma, N. and Sharma, N. (2018). Second generation bioethanol production from lignocellulosic waste and its future perspectives: A review. International Journal of Current Microbiology Applied Science, 7(5), 1285-1290; doi.org/10.20546/ijcmas.2018.705.155

Singh, D.P., and Trivedi, R.K. (2013). Acid and alkaline pretreatment of lignocellulosic biomass to produce ethanol as biofuel. International Journal of ChemTech Research, 5(2), 727-734.

Sitompul, P. J., Widayat, W., \& Soerawidjaja, H. T. (2012). Evaluation and Modification of Processes for Bioethanol Separation and Production. International Journal of Renewable Energy Development, 1(1), 15-22; doi.org/10.14710/ijred.1.1.15-22

Singhvi, M.S. and Gokhale, D.V. (2019). Lignocellulosic biomass: hurdles and challenges in its valorization. Applied microbiology and biotechnology, 103(23), 9305-9320; doi.org/10.1007/s00253-019-10212-7

Su, T., Zhao, D., Khodadadi, M. and Len, C. (2020). Lignocellulosic biomass for bioethanol: Recent advances, technology trends, and barriers to industrial development. Current Opinion in Green and Sustainable Chemistry, 24, 56-60; doi.org/10.1016/j.cogsc.2020.04.005

Sudiyani, Y., Triwahyuni, E., Muryanto, Burhani, D., Waluyo, J. Sulaswaty, A. and Abimanyu, H. (2016). Alkaline Pretreatment of Sweet Sorghum Bagasse for Bioethanol Production. International Journal of Renewable Energy Development, 5(2), 113-118; doi.org/10.14710/ijred.5.2.113118

Sun, S., Sun, S., Cao, X. and Sun, R. (2016). The role of pretreatment in improving the enzymatic hydrolysis of lignocellulosic materials. Bioresource technology, 199, 4958; doi.org/10.1016/j.biortech.2015.08.061

Tsegaye, B., Balomajumder, C. and Roy, P. (2019). Microbial delignification and hydrolysis of lignocellulosic biomass to enhance biofuel production: an overview and future prospect. Bulletin of the National Research Centre, 43(1), 1 16; doi.org/10.1186/s42269-019-0094-x
Wan, H.P., Hung, W.C., Lin, U.T., Chen, J.Y., Yu, P.J. and Yang, T.Y. (2018). Hydrolysis of lignocellulosic biomass in ionic solution. Journal of Chemical Engineering of Japan, 51(9); doi.org/786-793 10.1252/jcej.17we151

Wang, X. (2021). Pretreatment: Toward effectiveness and sustainability. In Advances in 2nd Generation of Bioethanol Production, Woodhead Publishing, 87-112; doi.org/10.1016/B978-0-12-818862-0.00011-X

Weerasinghe, W. M. L. I., Madusanka, D. A. T., and Manage, P. M. (2021). Isolation and Identification of Cellulase Producing and Sugar Fermenting Bacteria for SecondGeneration Bioethanol Production. International Journal of Renewable Energy Development, 10(4), 699-711; doi.org/10.14710/ijred.2021.35527

Winarsih, S. and Siskawardani, D.D. (2020). Hydrolysis of corncobs using a mixture of crude enzymes from Trichoderma reesei and Aspergillus niger for bioethanol production. Energy Reports, 6, 256-262; doi.org/10.1016/j.egyr.2020.11.141

Wipulasena, A. (14 October, 2018). Country generates 7,500MT waste daily: Strategic solutions key to fixing garbage crisis. Sunday Observer. Retrieved from https://www.sundayobserver.lk/2018/10/14/newsfeatures/country-generates-7500mt-waste-daily-strategicsolutions-key-fixing-garbage.

Woiciechowski, A.L., Neto, C.J.D., de Souza Vandenberghe, L.P., de Carvalho Neto, D.P., Sydney, A.C.N., Letti, L.A.J., Karp, S.G., Torres, L.A.Z. and Soccol, C.R. (2020). Lignocellulosic biomass: Acid and alkaline pretreatments and their effects on biomass recalcitrance-Conventional processing and recent advances. Bioresource technology, 304, 122848; doi.org/ 10.1016/j.biortech.2020.122848

Yang, L., Ru, Y., Xu, S., Liu, T. and Tan, L. (2021). Features correlated to improved enzymatic digestibility of corn stover subjected to alkaline hydrogen peroxide pretreatment. Bioresource Technology, 325, 124-688; doi.org/10.1016/j.biortech.2021.124688

Zabed, H., Sahu, J.N., Suely, A., Boyce, A.N. and Faruq, G. (2017). Bioethanol production from renewable sources: Current perspectives and technological progress. Renewable and Sustainable Energy Reviews, 71, 475-501; doi.org/10.1016/j.rser.2016.12.076

Zentou, H., Abidin, Z.Z., Yunus, R., Awang Biak, D.R. and Korelskiy, D. (2019). Overview of alternative ethanol removal techniques for enhancing bioethanol recovery from fermentation broth. Processes, 7(7), 458; doi.org/10.3390/pr7070458

Zhang, M., Wang, F., Su, R., Qi, W. and He, Z. (2010). Ethanol production from high dry matter corncob using fed-batch simultaneous saccharification and fermentation after combined pretreatment. Bioresource Technology, 101(13), 4959-4964; doi.org/10.1016/j.biortech.2009.11.010

Zoghlami, A. and Paës, G. (2019). Lignocellulosic biomass: understanding recalcitrance and predicting hydrolysis. Frontiers in chemistry, $7, \quad 874$; doi.org/10.3389/fchem.2019.00874. 